\title{
COPD: osteoporosis and sarcopenia
}

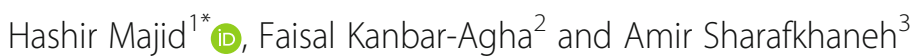

\begin{abstract}
Systemic involvement and comorbidities are common in chronic obstructive pulmonary disease (COPD). They add to the burden of disease and are associated with significant disability and mortality. These include cardiovascular disease, mood disorders, anemia, cachexia, skeletal muscle dysfunction and bone pathology. In this article, we review the pathophysiology, diagnosis and treatment of two such comorbidities, osteoporosis and sarcopenia, as they relate to patients with COPD.
\end{abstract}

\section{Introduction}

Chronic obstructive pulmonary disease (COPD) is a multisystem disorder, characterized by involvement of multiple organs in addition to the lungs [1]. The inflammatory state inherent to the lung pathology in COPD is thought to be the root cause of this multi-organ dysfunction. Furthermore, it is likely that this state contributes to the development and acceleration of comorbid conditions seen in COPD patients at higher frequencies when compared to the general population.

Currently, the delineation between a systemic feature and comorbidity of COPD is not well defined. Skeletal muscle dysfunction, cachexia, osteoporosis, coronary artery disease, congestive heart failure, anemia, metabolic syndrome, depression and anxiety are all frequently encountered in COPD patients. What is clear, however, is that all of the above lead to morbidity and mortality and need to be identified and addressed by the physician taking care of a COPD sufferer.

In this chapter, we will review osteoporosis and sarcopenia in patients with COPD.

\section{Review}

\section{Osteoporosis in COPD}

Osteoporosis is a silent "skeletal disorder characterized by compromised bone strength predisposing to an increased risk of fracture. Bone strength reflects the integration of two main features: bone density (in turn determined by peak bone mass and amount of bone

\footnotetext{
* Correspondence: hashir.majid@aku.edu

${ }^{1}$ Section of Pulmonary and Critical Care Medicine, Department of Medicine, Aga Khan University, Stadium Road, Faculty Office Building, PO Box 3500,

Karachi 74800, Pakistan

Full list of author information is available at the end of the article
}

loss) and bone quality (a function of bone architecture, turnover, damage accumulation and mineralization)" [2].

At present, except for markers for bone turnover, few indicators exist to concretely describe measures of bone quality. Hence, bone density remains the principal method to define osteoporosis. As per the World Health Organization criteria, a bone mineral density (BMD) score, measured by a dual energy X-ray absorptiometry (DXA) scan, that is 2.5 times or more below the standard deviation ( $\mathrm{T}$ score of -2.5 on the DXA bone scan) for a young normal population is used to define osteoporosis; a BMD score between -1 and -2.5 is indicative of osteopenia (low bone mass) [3].

\section{Epidemiology}

Osteoporosis is the commonest bone disorder to afflict humans [4]. Roughly 10 million Americans have osteoporosis and a staggering 43 million have osteopenia, placing them at risk for fractures $[5,6]$. Worldwide, the number of people with osteoporosis is estimated at 200 million [7]. With aging populations, the incidence and burden of osteoporosis and fractures are projected to get significantly worse [8].

Caucasian women constitute the largest at-risk group for osteoporosis; by age sixty, half of them suffer from osteopenia and one in two have an osteoporosis related fracture in their lifetime [4, 9]. However, both genders and all races are affected by the disease.

Despite the preponderance of men in the COPD population, osteoporosis is more common in COPD patients when compared to age matched controls without airflow limitation [10]. Roughly one-third of patients with COPD have osteoporosis (range 9-69\% - the wide interval reflecting differences in methodology and demographics 
of the study population, as well as the severity of disease in the various studies) and about 38\% have osteopenia (range 27-67\%) [10, 11]. The increased prevalence of bone loss and osteoporosis places COPD patients at a significant risk of developing fractures, especially vertebral compression fractures [12,13] and hip fractures [14].

\section{Pathophysiology}

Normal bone homeostasis The skeletal system is in a constant state of flux. Bone remodeling and resorption occur continuously to preserve the integrity of bone structure [15]. Osteoclasts, osteoblasts, and osteocytes, under the control of vitamin D, parathyroid (PTH) and gonadal hormones, are responsible for this process (Fig. 1). It is estimated that up to $25 \%$ of trabecular bone (the spongy bone located at the ends of long-bones and in vertebrae) and $3 \%$ of cortical bone (located in the shaft) are replaced every year [16, 17].

Osteocytes are cells that are embedded in the bone matrix. They detect microdamage, caused by mechanical fatigue, in the bones and initiate bone remodeling by interacting with osteoclasts and osteoblasts.

Damaged bone is resorbed by osteoclasts. These are multi-nucleate giant cells, from the monocyte/macrophage cell line, that secrete hydrolytic enzymes, including cathepsins and matrix metalloproteinases. Osteoclasts also secrete hydrogen and chloride ions. The resultant acidic environment aids bone resorption; it also activates the proteolytic enzymes, leading to breakdown of collagen/ matrix of the compromised bone. Osteoblasts, derivatives of mesenchymal stem cells, then complete the remodeling process by making new bone -both the organic matrix and mineral- at the damaged site.
Two signaling pathways, osteoprotegerin (OPG)/receptor activator of nuclear-factor kappa $\mathrm{B}(\mathrm{RANK}) /$ receptor activator of nuclear-factor kappa B ligand (RANKL), and $\mathrm{Wnt} / \beta$-catenin system, are important in regulating bone metabolism. RANKL, expressed on the surfaces of osteoblasts, bone stromal cells and activated T cells, binds with RANK present in osteoclast progenitor cells' cellular membranes and promotes maturation to osteoclasts; it also inhibits osteoclast apoptosis [18]. Bone resorption is thereby enhanced. OPG, also made by osteoblasts and bone stromal cells, inhibits these processes by binding to RANKL and preventing it from adhering to $\operatorname{RANK}[19,20]$.

The Wnt/ $\beta$-catenin signaling system promotes bone formation. It does this by a number of mechanisms: by promoting preferential differentiation of mesenchymal stem cells to osteoblasts rather than adipocytes, by inhibiting osteoblast apoptosis, and by increasing the levels of OPG.

Osteoporosis in COPD An imbalance in the processes of bone resorption and formation, either excessive resorption or decreased bone formation, leads to osteoporosis. A number of changes, leading to this imbalance, have been observed in COPD patients with osteoporosis:

- Elevated levels of RANK and RANK/OPG ratio [21]

- Upregulation of RANKL [21]

- Lower levels of OPG [22]

- Decreased activity of Wnt/ $\beta$-catenin signaling [23]

- Elevated levels of matrix metalloproteinases [24]

The inflammatory milieu observed in COPD patients, especially the emphysema phenotype, is thought to

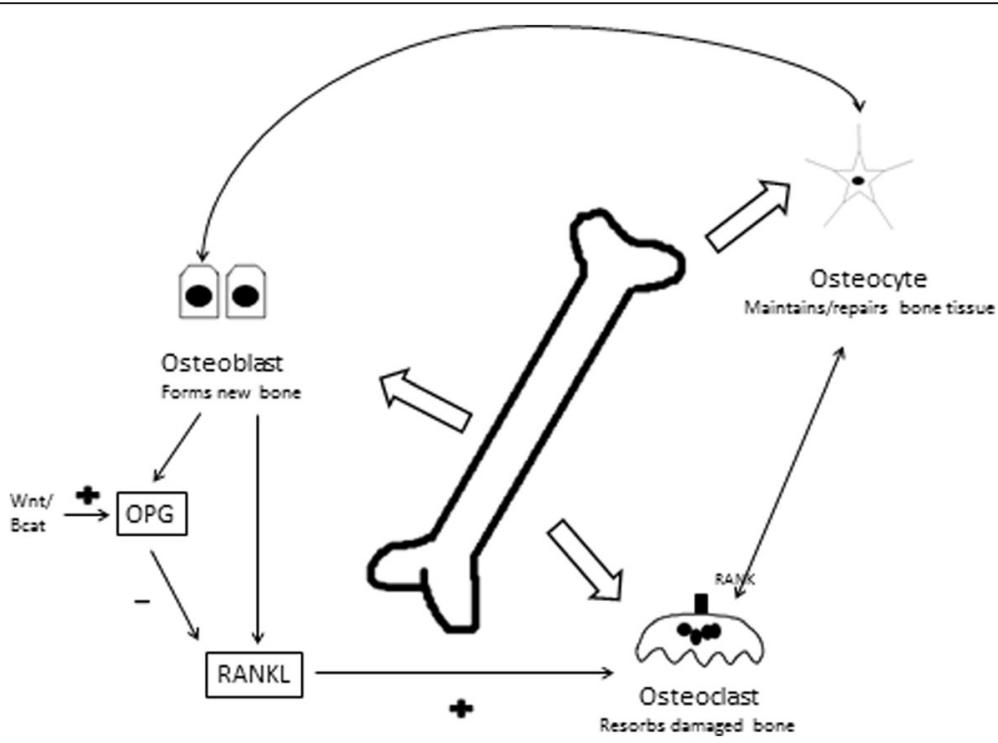

Fig. 1 Simplified diagram representing normal bone homeostasis. OPG = osteoprotegerin, RANK = receptor activator of nuclear-factor kappa-B, $\mathrm{RANKL}=$ receptor activator of nuclear-factor kappa-B ligand, $\mathrm{Wnt} / \mathrm{Bcat}=\mathrm{Wnt} / \mathrm{B}$-catenin 
contribute to these changes, particularly the OPG/ RANK/RANKL axis. Interleukin-1 (IL-1) and tumor necrosis factor- $\alpha$ (TNF $\alpha$ ), levels of which are significantly increased in COPD (along with IL-6), favor RANKL activity and promote osteoclastogenesis and, ultimately, osteoporosis $[25,26]$. The degree of radiolographically evident emphysema is directly correlated to lower levels of BMD in COPD patients [21].

In addition to the above, various other factors promote osteoporosis in COPD patients. These are described below.

\section{Use of corticosteroids}

Corticosteroids, inhaled and systemic, affect all three major cells involved in bone homeostasis, tilting the balance in favor of bone resorption and increasing the risk of fractures. They decrease levels of OPG and enhance expression of RANKL and monocyte/macrophage-colony stimulating factor (M-CSF) - M-CSF, similar to RANKL, stimulates osteoclastogenesis [27-29]. By inhibiting the Wnt/ $\beta$-catenin pathway, they also decrease the proliferation, differentiation and maturation of osteoblasts; bone formation is decreased resultantly [30, 31]. Lastly, corticosteroids adversely affect the ability of osteocytes to detect microdamages and make bones more susceptible to fractures [32]. Osteocyte apoptosis is promoted, making the bones harder, less vascular and more brittle [33-35].

Steroids, in inhaled or systemic form, are used for specific indications in COPD patients.. Inhaled corticosteroids (ICSs) decrease the frequency of exacerbations and improve quality of life in moderate-to-severe disease $[$ FEV $<60 \%$ ] [36-39]. Systemic steroids are the cornerstone of therapy in COPD exacerbations and decrease their duration, improve symptoms and prevent relapse [40-45]. However, use of steroids comes at a cost with significant adverse effects, including osteoporosis and fractures. Systemic steroid usage is a predictor of decreased BMD and fracture occurrence [46-48]. The risk is dose dependent, with the highest risk of fractures in the first three to six months after initiation of therapy, and resolution of the risk within one year of treatment cessation [49].

The correlation between ICSs and reduced BMD and fractures is less clear. One long term follow-up of high dose triamcinolone [50] and a systematic review of ICSs revealed lower BMD and a modest increase in fractures respectively [48], but other studies have not corroborated this evidence with high dose ICSs [51-53]. Interestingly, at low doses, ICSs may prevent osteoporosis in COPD patients by decreasing the systemic inflammatory milieu [54].

\section{Vitamin D deficiency}

Low levels of vitamin D cause a drop in serum calcium [55]. A compensatory elevation of PTH occurs leading to production and release of calcitriol from the kidneys; calcium levels are normalized by the actions of calcitriol on the gut and the bones [56]. Calcitriol induces RANKL expression on osteoblasts and hence leads to excess resorption of the bones [and release of calcium]. The resultant normalization of serum calcium suppresses $\mathrm{PTH}$ production from the parathyroid gland. With vitamin D deficiency, this homeostatic control is lost; unchecked PTH release and its action lead to osteoporosis.

Vitamin D deficiency, defined as serum 25-hydroxyvitamin D levels of $<20 \mathrm{ng} / \mathrm{ml}$ [57], is quite prevalent in COPD. There are many reasons for this, including poor dietary intake, decreased 25-OH D production from senescent skin (a result of smoking), poor sunlight exposure due to COPD induced functional and mood impairment, renal dysfunction and steroid use [58]. Up to two-thirds of COPD patients can have a vitamin $\mathrm{D}$ deficiency, and the prevalence increases with the severity of airflow limitation (approximately $40 \%$ in GOLD stage I, rising to $~ 80 \%$ in GOLD stage IV) [59-61].

Lastly, vitamin D deficiency increases the risk of fractures due to its beneficial effects on balance and muscle strength [62]. Vitamin D supplementation in elderly patients with deficiency, especially in conjunction with calcium, results in a lower risk of falls and fractures [63].

\section{Hypogonadism}

The human sex hormones play an important role in maintaining skeletal integrity in the adult, by promoting bone formation and inhibiting resorption $[64,65]$. Estradiol, in particular, is clearly implicated, with low levels being strongly associated with bone loss and fractures [66, 67]. Hypogonadism is common in COPD patients, various studies indicating a prevalence rate range of $22-69 \%$, and is associated with osteoporosis and muscle weakness [68].

\section{Reduced body mass index, fat free mass, sarcopenia and reduced physical activity}

Mechanical loading plays an important role in maintaining bone mass and integrity [69]. The osteocyte network senses and transduces strain to the effector cells, osteoclasts and osteoblasts, to decrease bone resorption and enhance bone formation at sites where more strength is required to counter stress. Decreased mechanical stress, as occurring in low gravity, disuse and reduced physical activity, lead to bone loss [70-73].

The reduced mechanical load on bones that occurs with decreased body mass index [BMI], fat free mass [FFM] and with sarcopenia, can reduce bone formation. Physiological derangements in body composition are common in patients with COPD, with a high prevalence of low BMI, and low FFM [cachexia], and sarcopenia (reduced muscle strength and mass). Up to a third of 
COPD patients suffer from low BMI, low FFM or sarcopenia $[74,75]$. A significant correlation with osteoporosis has been observed in patients with COPD and sarcopenia, low BMI or low FFM [76, 77]. Besides a decreased mechanical load, other factors that may link osteoporosis and sarcopenia/low FFM/low BMI are vitamin $\mathrm{D}$ deficiency, inflammatory mediators, genetic factors, and the use of corticosteroids.

Sarcopenia is also related to impaired physical mobility, physical ability and falls with a higher risk of fractures [78].

\section{Anemia and hypoxia}

Hypoxia, by inhibiting stem cell differentiation into osteoblasts via decreased expression of transcription factor (Cbfa-1/RUNX2), reduces bone formation, while strongly stimulating osteoclast formation and bone resorption $[79,80]$. Anemia is also thought to be associated with osteoporosis because of the same mechanism, as a result of anemia induced decreased tissue oxygen delivery. Both conditions are commonly seen in COPD patient, especially with severe disease, and are likely to contribute to COPD associated osteoporosis [81-83].

\section{Others}

Hypercapnia: A significant proportion of COPD patients have chronic carbon dioxide retention [84]. As expected, more severe airflow limitation (with reduced FEV1 and high airway resistance) is associated with hypercapnia. Elevated carbon dioxide levels, even in the absence of acidosis, are potent stimulators of osteoclast activity and are associated with low BMD [85].

Smoking: A meta-analysis of over 40,000 subjects indicated that cigarette smoking, the most important risk factor for COPD, has an independent, dose-dependent effect on BMD and risk of fractures, that is partially reversible with cessation of smoking [86]. Smoking contributes to osteoporosis through a variety of mechanisms, including effects on estradiol activity [87], as well the as Vit D/PTH axis [88], increased free radicals and oxidative stress resulting in more bone resorption [89], and modulation of OPG/RANK/RANKL system [90].

COPD exacerbations: These have been shown to be an independent risk factor for progression of osteoporosis [91]. The mechanism involved is likely a combination of factors discussed above: augmentation of the systemic inflammatory state during an exacerbation, worsening hypoxia and hypercapnia, elevated MMP levels, oxidative stress, use of steroids, and physical inactivity [92].

Age and gender: Older age is a common risk factor for both COPD and osteoporosis. After reaching peak bone mass in the middle-to-late twenties, people have gradual, continuous bone loss as they grow older. This bone loss is accelerated in women in the peri- and postmenopausal period [93].
Clinical features and consequences of osteoporosis in COPD

Osteoporosis is asymptomatic unless it is complicated by a fracture, with its accompanying physical, psychosocial and financial sequelae. Unlike people with healthy bones, patients with osteoporosis are susceptible to fractures from minor mechanical stress or trauma [94, 95]. These are termed as fragility fractures.

The commonest site of fracture with osteoporosis is the vertebral column. The thoracolumbar junction (T12-L1) and mid-to-lower thoracic area (T7-T8) are usually affected in patients with COPD [96]; various studies report a vertebral compression fracture (VCF) rate of $24-63 \%$ in COPD [13, 97-99]. Other commonly involved areas include the hip and the ribs.

Fractures are associated with significant morbidity and mortality in osteoporotic, COPD patients. Vertebral compression fractures can cause pain and result in kyphosis, decreased rib cage excursion and lung volumes [100]; an increased frequency of COPD exacerbations secondary to an impaired ability to expectorate can occur with the hypoventilation related to rib fractures [101]. It is estimated that each VCF is associated with a 9\% drop in vital capacity [102]. VCFs also increase the rate and duration of hospitalization, and are associated with a worsened health-related quality of life [103, 104]. Worryingly, VCFs often escape detection, especially when they are not painful (which is the case in a massive 60$70 \%$ of VCF cases), leading to a missed opportunity to treat osteoporosis and prevent further fractures $[105,106]$. Approximately, one in five patients who sustain a VCF suffer another VCF within a year [107].

Hip fractures have the highest impact on health and survival among osteoporosis related fractures, especially in the elderly. They are associated with a significant rate of death (one year mortality rate of $14-36 \%$, including a $4 \%$ mortality rate for the corrective surgery itself) [108-110], as well as a loss of mobility and independence, increased need for institutionalization and healthcare utilization, high cost, mood and cognitive impairment, and a higher risk of subsequent fractures [111]. The risk of death after a hip fracture is $60-70 \%$ higher in COPD patients when compared to those without COPD [112]. At present, the exact incidence and prevalence of hip fractures in COPD is not well studied. However, in two large cohorts, COPD was found to be associated with a higher risk of hip fractures (23\% for women, 30\% for men) and a higher rate of occurrence when compared to the general population [113, 114].

\section{Diagnosis}

Osteoporosis is commonly missed. Even when resulting in fractures, diagnosis and treatment can be overlooked. Up to a third of VCFs are missed, and even when fragility fractures are picked up, physicians can 
fail to look for osteoporosis and place patients on appropriate treatment [115-117].

Every patient with COPD should have a risk evaluation performed by his physician to assess the likelihood of a future fracture risk. FRAX is a useful tool developed by the $\mathrm{WHO}$ for predicting a ten-year risk of fractures [118]. It uses ten clinical predictors to calculate this probability. These include gender, age, height, weight, and prior or current history of fragility fracture, smoking, corticosteroids use, alcohol consumption, rheumatoid arthritis and parental fracture. FRAX can be used with or without a BMD score. However, it should be noted that FRAX can underestimate the risk of fracture in COPD [119-121]. To improve the accuracy of its prediction, a modified FRAX with the addition of severity of airflow limitation assessed by FEV1, degree of physical inactivity, and a history of recent fall, has been proposed. This model, however, has not yet been validated [122].

A diagnosis of osteoporosis is confirmed by demonstration of either a low BMD or a fragility fracture of the hip or spine [123]. Laboratory tests to rule out secondary causes of osteoporosis (e.g. type 1 diabetes, hyperthyroidism, chronic malnutrition, chronic liver disease etc.) should be performed if a clinical evaluation is suggestive of such conditions.

The current gold standard for the diagnosis of osteoporosis is the dual-energy X-ray absorptiometry (DXA) test [124]. This assesses bone mass by measuring bone mineral density, generally at the femoral neck or lumbar spine. Areal BMD is calculated by comparing the absorption by a subject's bone of two different energy-level low radiation X-ray beams. It is then compared with either the BMD of a healthy gender-matched early adult cohort to obtain a t-score, or (for premenopausal women, men $<50$ years of age, and children) with age-, gender-, and ethnicity-matched reference population to obtain a $\mathrm{z}$-score [3]. T-scores of -2.5 or lower, i.e. a BMD that is 2.5 standard deviations below the reference population, confirm osteoporosis. Scores between -2.5 and -1 indicate osteopenia, while a score above -1 is considered normal [125]. When a z-score is used, a cutoff of -2 is used to differentiate between normal and low BMD "for expected range for age" [126]. A one standard deviation drop in score is associated with a 1.5-3 times higher risk of fracture [127]. DXA scans should be interpreted with caution in individuals with small body frames or with degenerative disease of the spine. DXA may overestimate or underestimate the risk of fractures in these situations respectively [128].

DXA scans are also used for monitoring the progress of osteoporosis and its response to treatment. These should generally be performed at 2 year intervals in otherwise healthy patients with osteoporosis, as DXA is usually unable to detect significant changes in BMD earlier than this period [129]. With corticosteroid therapy, osteoporosis is accelerated. Therefore, consideration should be given to performing DXA scans more frequently, possibly annually, in COPD patients who are currently or have been on steroids [130].

The presence of a VCF, even when BMD results are not available, is sufficient to establish a diagnosis of osteoporosis [123]. VCFs are diagnosed by lateral thoracic and lumbar X-rays or by lateral vertebral fracture assessment on DXA scan [131]. VCFs can often be picked up on chest $\mathrm{X}$-rays, and should actively be looked for when reviewing chest imaging of COPD patients [12, 132]. A decrease in height by more than $4 \mathrm{~cm}$ from age 25 , should alert the physician to the possibility of a VCF [133].

Other means of assessing bone strength include biochemical markers of bone turnover, CT-based absorptiometry, and quantitative ultrasound densitometry [128, 134]. However, at present, these are not widely available in routine clinical practice and are mostly used for research purposes.

\section{Treatment of osteoporosis in COPD}

The osteoporosis literature focuses almost exclusively on post-menopausal women and the elderly for obvious reasons. There is a dearth of studies specific to osteoporosis in the COPD population. Till more data is available for this population, the management of osteoporosis in COPD should follow established guidelines for primary osteoporosis [123].

Physicians should avoid excessive glucocorticoid use, inhaled and systemic, as a general principle when managing COPD, due to their significant side effects. Inhaled corticosteroids, in low to medium doses if possible, should be restricted to patients with FEV1 $<60 \%$ with a history of recurrent COPD exacerbations [37]. High dose inhaled corticosteroids are associated with a higher risk of pneumonia [36]. Short duration of systemic corticosteroids in medium doses are the preferable treatment for most patients with an acute exacerbation as outcomes with such a regimen are similar to doses given for longer duration [135].

\section{Non-pharmacological interventions}

Lifestyle modifications conducive to maintaining bone strength should be encouraged. Excessive alcohol intake daily consumption of more than two drinks for women, and three for men - can lead to deleterious effects on bone health and increased risk of fall, and should be discouraged; individuals should be assessed for the possibility of alcoholism and managed appropriately [136]. Fall risk should be assessed for individual patients and interventions that decrease their risk should be implemented; strategies include withdrawal of psychotropic medications, exercise programs [including Tai Chi], and home 
safety assessment and modification by an occupational therapist [123].

Other lifestyle changes have a positive impact on both osteoporosis and COPD (Fig. 2). These include quitting tobacco, improving diet [especially calcium and vitamin D], and engaging in exercise programs. Smokers should be enrolled in smoking cessation programs; tobacco cessation leads to improved respiratory function [137] and modest improvements in BMD [138]. Exercise programs, especially when performed in a multi-disciplinary setting, confer significant health benefits to COPD sufferers, improve bone density and decrease the risk of falls and fractures [139-142].

\section{Pharmacological interventions}

\section{Indications for pharmacological treatment for osteoporosis} in COPD

Treatment for osteoporosis should be considered if patients with COPD have a history of a fragility fracture or have been using systemic corticosteroids for three months/year. Other criteria include low BMI $\left(<21 \mathrm{~kg} / \mathrm{m}^{2}\right.$, active smoking, significant alcohol use, age above 65 , rib fracture, physical inactivity, menopause, $\mathrm{FEV} 1<50 \%$ and parental hip fracture) [143]. Initial therapy should focus on ensuring adequate intake of calcium and vitamin D with or without additional medications.

\section{Calcium and vitamin $D$}

Calcium and vitamin D play an important part in preventing and treating osteoporosis. As mentioned before, vitamin $\mathrm{D}$, in conjunction with calcium supplementation, decreases the risk of falls by improving stability and strength. Adequate dietary intake of both should be advised. A combination of supplemental calcium and vitamin $\mathrm{D}$ can decrease the risk of osteoporotic fractures [144]. The recommended dietary allowance [RDA] for calcium is $1,000 \mathrm{mg} /$ day for men aged $51-70$ and $1,200 \mathrm{mg} /$ day for women above 50 and men above 70 [145]. The RDA for vitamin D is 600 international units/ day for adults aged 51-70 and $800 \mathrm{IU} /$ day for older individuals. Patients should be encouraged to meet their RDA through dietary intake (fruits, vegetable, dairy products fortified with vitamin $\mathrm{D}$, fish, liver); if this proves inadequate, supplements should be prescribed. Caution should be exercised with using excessive doses of both, as there is a risk of toxicity with high doses of vitamin D [146] and a possible, controversial, link with renal stones and cardiovascular events with calcium intake above 1200-1500 mg/day [147-149]. Daily intake of up to 4,000 IU/day of vitamin D is generally considered as a safer upper limit.

\section{Teriparatide}

Teriparatide is a biosynthetic form of human PTH. It is the only FDA approved anabolic treatment of osteoporosis

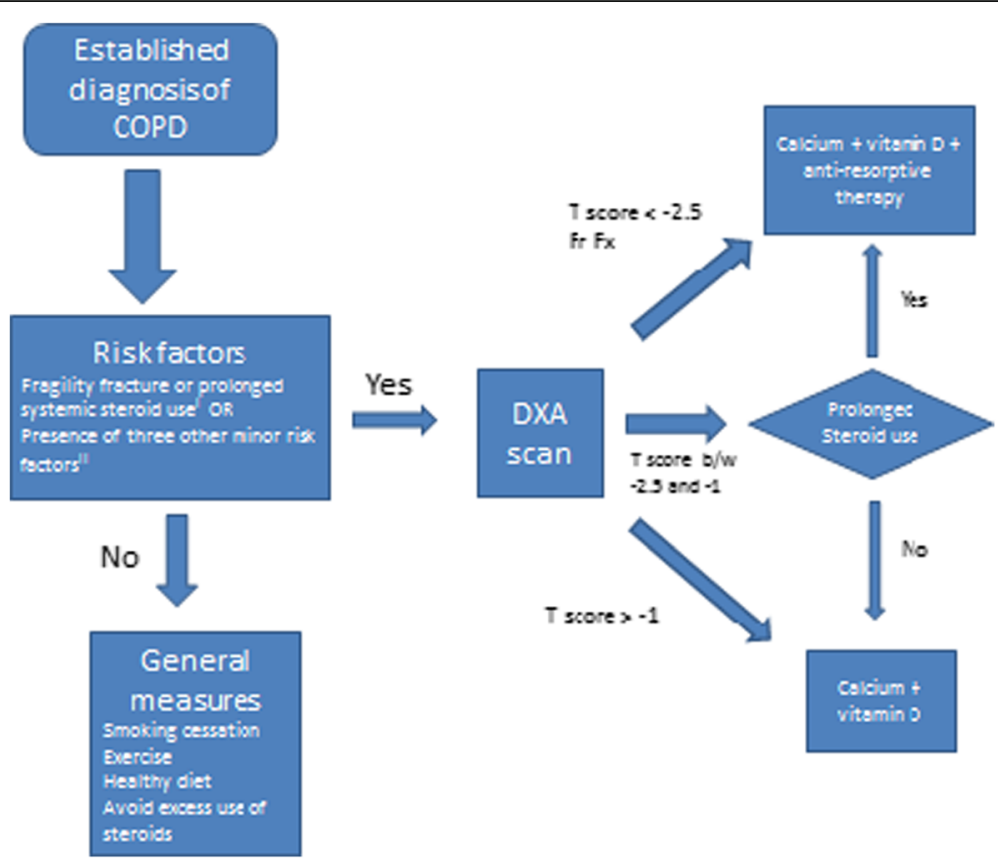

Fig. 2 Schematic diagram summarizing risk factor assessment, diagnosis and treatment for osteoporosis in COPD. 'Fragility fracture is defined as a fracture of the hip or spine; prolonged systemic steroid use duration is defined as 3 months. "Risk factors include: BMI $<21$, active smoking, daily significant alcohol intake, age $>65$ years, menopause, rib fracture, inactivity, FEV1 $<50 \%$, parental hip fracture. Fr Fx = Fragility fracture 
available so far [150]. When used intermittently, teriparatide stimulates bone formation by promoting differentiation of osteoblasts from mesenchymal stem cells, activating preexisting osteoblasts and inhibiting their apoptosis.

Teriparatide decreases the risk of VCF by two-thirds and non-VCFs by half in patients with osteoporosis when given for an average of 18 months [151]. It is superior to alendronate in preventing osteoporosis in patients on glucocorticoid therapy [152, 153]. Treatment duration should generally not exceed two years when using the medication. Unlike bisphosphonates, its effect wears off quickly; alternate therapy should be initiated when stopping teriparatide.

In high doses for prolonged duration, teriparatide increases the incidence of osteosarcoma in animal models. Its use is hence contraindicated in patients at a high risk of osteosarcoma, i.e. those with a history of skeletal malignancy, bone metastases, radiation treatment of bones, and Paget's disease.

\section{Anti-resorptive treatment Bisphosphonates}

The most commonly used medications for osteoporosis treatment, bisphosphonates are synthetic analogues of pyrophosphates, a naturally occurring substance, with high affinity for hydroxyapatite in the bone [154]. Bisphosphonates inhibit osteoclast activity by blocking a key enzyme, farnesyl pyrophosphate synthase, and promote osteoclast apoptosis, ultimately decreasing bone resorption [155].

Bisphosphonates have a well-established role in treating osteoporosis and decreasing the risk of fractures, particularly VCFs, in post-menopausal women and those on glucocorticoids [156, 157]. Most bisphosphonates decrease VCF incidence by $40-50 \%$ and non-VCF by around $20-30 \%$. They also improve lumbar spine bone density scores in patients with airway disease [158]. Bisphosphonates are generally well tolerated. Gastrointestinal disturbance is the most common side effect with oral formulations. Oral medications should be avoided in patients who are unable to sit up straight for half an hour after ingesting the medication, in those with severe upper gastrointestinal symptoms or with significant esophageal pathology (e.g. dysmotility, stricture, achalasia). Uncommon side effects include atypical fracures, atrial fibrillation and osteonecrosis of the jaw [159].

\section{Calcitonin}

Calcitonin transiently decreases osteoclastic activity without affecting collagen synthesis by osteoblasts [160]. Salmon-calcitoinin is available in oral and nasal forms and decreases the risk of VCFs by about a third with no significant impact on the incidence of non-vertebral fractures [161]. It is very much a second line medication, used for those unable to take bisphosphonates, due to a small increase in risk of malignancies associated with the drug [162], and better efficacy of other medications. Calcitonin may have some use in the setting of acute osteoporotic fractures due to its adjunctive effect of pain relief which helps in earlier mobilization [163].

\section{Denosumab}

This monoclonal antibody against RANKL inhibits osteoblast differentiation, activation and survival, thereby decreasing osteoclastogenesis [164]. It decreases the risk of VCFs by two-thirds, hip fracture by $40 \%$ and non-VCFs by $20 \%$ [165] and improves BMD in post-menopausal women [166]. It is superior to most bisphosphonates in its effect on BMD [167, 168]. Efficacy is greater with combination therapy of both denosumab and teriparatide [169]. Denosumab is injected subcutaneously every 6 months by a health professional. Side effects include risk of hypocalcemia, cellulitis and skin rash.

\section{Estrogen agonist/antagonist compounds (previously known as Selective Estrogen Receptor Modulators)}

This group of medications binds to intracellular estrogen receptors, acting as either agonists or antagonists in different tissues [170]. In bones, these compounds improve BMD and decrease the risk of osteoporosis associated VCFs [171]. They are approved for use in post-menopausal women.

\section{Duration of treatment and follow-up}

The need for continuing therapy should be periodically re-evaluated intervals due to the risk of side effects with medications. The risk of atypical femoral fractures and osteonecrosis of the jaw increases when on treatment beyond five years. The effect of non-bisphosphonate medications is temporary and wanes after cessation of therapy. In contrast, bisphosphonates can have residual treatment effects that last for several years [172].

Patients should be monitored at regular intervals. Compliance with medications, adequacy of calcium and vitamin D intake, level of physical activity and risk of fall should be assessed. Annual accurate height measurements should be performed; a loss of height by $2 \mathrm{~cm}$ is an indication for vertebral imaging [123]. Serial DXA scans should be performed to check BMD. Vitamin D levels should be monitored. The decision on the duration of treatment should be made after assessing all of the above in each individual patient separately. For patients with low-to-moderate risk of fall and fractures, medications may possibly be stopped. In case of a high risk for fracture, treatment should be continued [173]. 


\section{COPD and sarcopenia}

Skeletal muscles play a critical part in metabolism and overall functional health. Sarcopenia is a syndrome characterized by progressive decrease of muscle mass and strength. It is estimated that after the age of fifty, healthy adults lose roughly $1-2 \%$ of their skeletal muscle each year. Underlying mechanisms for this age-related muscle loss include malnutrition, physical inactivity, hypogonadism and chronic inflammation. Progressive muscle loss can also occur in multiple disease states, such as cancer, heart failure, HIV, end-stage renal disease, end-stage liver disease, COPD and in prolonged illness [174]. Muscle mass loss is prevalent in patients with COPD as a result of both the disease and aging [175].

The prevalence of sarcopenia increases with age. An estimated $15 \%$ of people older than 65 years are affected by the condition; in those above the age of 80 , the proportion of affected individuals is as high as 50\% [176]. Sarcopenia places a significant public health and economic burden, with an estimated $\$ 18.5$ billion spent on its treatment in 2000 [177].

Sarcopenia is quite common in COPD, with quadriceps weakness being observed in a third of COPD outpatients, even in individuals exhibiting mild to moderate airway obstruction [74, 75, 178]. It contributes significantly to a diminution of exercise capacity, reduced quality of life, increased healthcare utilization, and premature mortality $[179,180]$. Given the substantial morbidity and mortality associated with sarcopenia, significant effort is being expended to identify strategies for prevention, early diagnosis and treatment of sarcopenia in high risk individuals. Whether these strategies will improve survival in such individuals is yet to be ascertained [181].

\section{Pathophysiology}

Muscle dysfunction in COPD is a consequence of reduction in muscle mass, altered muscle metabolism and a shift in muscle fiber composition.

Muscle strength and endurance are both adversely affected. At the cellular level, this dysfunction is thought to be due to an imbalance favoring protein breakdown over synthesis, apoptosis, sarcomere and sarcolemma damage, reduced myosin heavy chain-I isoform type I [slow twitch/endurance] muscle fibers, and a decreased density of capillaries and mitochondria [182-188]. Abnormalities in essential oxidative enzymes, mitochondrial activity and expression of myogenin and $\mathrm{m}$-cadherin- key molecules required for muscle growth and repair- also contribute to the pathology [189].

At present, the exact reason for these changes in COPD patients is unclear; it is thought that a variety of mechanisms are responsible. These include poor peripheral oxygenation (due to COPD related gas exchange abnormalities and anemia, leading to inflammation, oxidative stress, apoptosis and poor muscle repair) [190-192], systemic inflammatory state particularly during exacerbations (inhibits muscle contractions, activates catabolic systems such as ubiquitin proteasome, leads to oxidative stress and causes apoptosis) [193-195], oxidative stress (linked to systemic inflammation, with an imbalance between reactive oxygen species and antioxidants) [196, 197], hypercapnia (leading to acidosis and impaired muscle proteostasis) [198, 199], diminished effect of anabolic hormones such as growth hormone and testosterone [189], net catabolic state [200], effect of tobacco (through a number of the aforementioned mechanisms) [201], myopathy induced by use of corticosteroids (especially systemic steroids) [202, 203], malnutrition/ negative energy balance [200, 204], and decreased physical activity leading to muscle disuse [205-207].

The last putative mechanism, i.e. sedentary behavior due to the breathlessness caused by COPD, might be the most important factor contributing to skeletal muscle dysfunction. Evidence pointing to its central role in sarcopenia pathogenesis includes disproportionate impairment of lower limb musculature in comparison to the upper limbs (that are subjected to a lesser degree of physical inactivity than the legs) [208], similarity in the structural changes seen in the sarcopenia of COPD and atrophy due to muscle disuse [209], partial recovery of strength with muscle training and conditioning $[210,211]$, and the apparent lack of correlation between the severity of airflow limitation and extent of muscle dysfunction [212].

Clinical features and consequences of sarcopenia in COPD The loss of muscle strength and function leads to limitation of activity, decrease in mobility, slow gait, poor stamina and, overall, general frailty [213]. Risk of falls and subsequent fractures, due to prevalent comorbid osteoporosis in this population, is increased. The consequences of fractures in COPD patients have been outlined in the osteoporosis section of this article. Lastly, in addition to diminished exercise capacity and health status, presence of sarcopenia is an independent predictor for mortality in patients with COPD [75, 179, 180, 214].

\section{Diagnosis}

The diagnosis of sarcopenia is confirmed in the presence of low muscle mass in addition to decreased muscle strength and/or reduced physical performance [215]. The most accurate diagnostic tests are generally used in a research setting; constraints due to cost, availability, and ease of use limit their clinical application (e.g. the most precise measurements of muscle mass are obtained with whole body imaging using CT scan or MRI; however, the cost, lack of easy access and concerns about 
radiation exposure make it difficult to use these modalities in routine clinical practice). Proposed diagnostic methods to ascertain muscle mass, strength and performance in clinical practice are listed in Table 1.

DXA allows quantification of body components (bone mineral, fat, and bone-mineral-fat-free mass) by detecting the relative attenuation of two different energy $\mathrm{X}$-rays by the body; radiation exposure is minimal and calculated muscle mass is similar to findings obtained on whole body imaging [216]. Bioimpedance analysis can also be used to measure muscle mass, especially when a portable alternative to DXA is required [217]. Anthropometric measures (e.g. calf and mid-upper arm circumference, skin fold thickness) are vulnerable to error and are not recommended for use in clinical practice [218].

Muscle strength is routinely assessed with the use of a handheld dynamometer to measure handgrip strength. It is reliable, easy to perform and inexpensive [219]. Isometric handgrip strength correlates well with power in the lower extremities and is a strong predictor of disability and mortality [219].

Measures of physical performance include gait speed alone or as part of the short physical performance battery test [where an individual is asked to perform a few physical maneuvers including ability to stand with feet in tandem/semi-tandem position, walk $8 \mathrm{ft}$, and get up from a chair and sit down five times], and the timed getup and go test (measures the time required for a subject to get up from a chair, walk a short distance, turn around and sit back down) [215]. These tests measure balance, strength, endurance and gait. A cut-off gait speed of $0.8 \mathrm{~m} / \mathrm{s}$ is a useful screening tool for predicting risk of sarcopenia [220].

\section{Treatment}

Exercise is the only modality known, to date, to prevent and improve muscle dysfunction [221, 222]. Resistance training, either through traditional strength training or functional strength training (which mimics activities of daily living), increases muscle mass and power and perception of well-being [223, 224].

Pulmonary rehabilitation significantly improves exercise capacity, severity of dyspnea and health-related quality of life in COPD subjects, including in patients with baseline normal exercise capacity $[225,226]$.

Table 1 Diagnostic testing for sarcopenia

\begin{tabular}{ll}
\hline Muscle mass & $\begin{array}{l}\text { a. Dual energy X-ray absorptiometry (DXA) } \\
\text { b. Bioimpendence analysis (BIA) } \\
\text { Muscle strength }\end{array}$ \\
Physical performance & Handheld dynamometer \\
& $\begin{array}{l}\text { a. Gait speed } \\
\text { b. Timed Up and Go (TUG) } \\
\text { c. Short Physical Performance Battery (SPPB) }\end{array}$ \\
\hline
\end{tabular}

Sarcopenia does not appear to diminish the impact of pulmonary rehabilitation on these outcomes. Moreover, a small proportion of patients appear to have reversal of their muscle dysfunction with pulmonary rehabilitation [227].

There is no definite evidence supporting the use of nutritional supplements - antioxidants, creatine, amino acid combinations, for sarcopenia at present [204]. Optimization of vitamin D levels and protein intake [1-1.5 $\mathrm{g} / \mathrm{kg} /$ day] is recommended for all patients with sarcopenia [228].

A number of medications that could potentially treat sarcopenia associated with disease and aging are being developed. These include medications that work through the growth hormone/insulin-like growth factor 1 pathway (ghrelin mimetics/growth hormone secretagogues) [229, 230], selective androgen receptor modulators (SARMs), and agents that work through the myostatin/ acitivin A pathway.

The use of anabolic steroids and testosterone for muscle atrophy has been limited by their associated adverse effects, e.g. worsening of prostatic hyperplasia or cancer in men, virilization in women, and cardiovascular events [231, 232]. Medicines with selective anabolic activity in bones and muscles, with no effect on levels of luteinizing hormone and which are not converted to dihydrotestosterone or estradiol, would have a favorable risk/benefit ratio and would be ideal for the treatment of sarcopenia. Enobosarm, a non-steroidal SARM, appears to have these properties and has shown promising results in phase II trials, with improvement in muscle and bone mass and little effect on other androgen-sensitive tissues [233].

Other medications under development include agents that work through the myostatin/activin pathway. Myostatin is a molecule from the transforming growth factor B (TGF-B) superfamily that is upregulated in diseases associated with cachexia and has been strongly linked to muscle wasting by binding and activation of the activin receptor. Inhibitors of this pathway cause regeneration of muscle mass and improvement in muscle performance in animal models [234, 235]. It remains to be seen whether these therapies will prove to be effective in humans.

\section{Conclusion}

Osteoporosis and sarcopenia are common in COPD and are associated with significant disability and mortality. Despite a high prevalence, osteoporosis and sarcopenia are underdiagnosed and undertreated in patients with COPD. Osteoporosis increases the risk of fractures, while sarcopenia contributes to significant functional limitation. Physical activity/exercise, especially in the form of a multi-disciplinary pulmonary rehabilitation program, has a cardinal role in the prevention and treatment of both conditions. Ensuring adequate vitamins' 
levels and nutritional intake, and smoking cessation are also important. Pharmacological therapy for osteoporosis consists of anti-resorptive medications and teriparatide; so far, there are no commercially available drugs for the treatment of sarcopenia, although many promising agents are in the process of being developed. There remains a pressing need for further research related to both conditions and formulation of guidelines for their management, specifically in COPD subjects.

\section{Acknowledgements}

Not applicable.

\section{Funding}

Not applicable.

\section{Availability of data and materials}

Not applicable.

\section{Authors' contributions}

HM drafted and revised the manuscript. FKA drafted and revised the manuscript. AS drafted and revised the manuscript. All authors read and approved the final manuscript.

\section{Competing interests}

The authors declare that they have no competing interests.

\section{Consent for publication}

Not applicable.

\section{Ethics approval and consent to participate}

Not applicable.

\section{Author details}

'Section of Pulmonary and Critical Care Medicine, Department of Medicine, Aga Khan University, Stadium Road, Faculty Office Building, PO Box 3500, Karachi 74800, Pakistan. ${ }^{2}$ Detroit Medical Center, Detroit, MI, USA. ${ }^{3}$ Baylor College of Medicine, and Michael E. DeBakey VA Medical Center, Houston, TX, USA.

Received: 6 October 2016 Accepted: 23 November 2016

Published online: 08 December 2016

\section{References}

1. Vestbo J, Hurd SS, Agustí AG, Jones PW, Vogelmeier C, Anzueto A, Barnes PJ, Fabbri LM, Martinez FJ, Nishimura M, Stockley RA, Sin DD, RodriguezRoisin R. Global strategy for the diagnosis, management, and prevention of chronic obstructive pulmonary disease: GOLD executive summary. Am J Respir Crit Care Med. 2013;187(4):347-65

2. Klibanski A, Adams-Campbell L, Bassford TL, Blair SN, Boden SD, Dickersin K, et al. Osteoporosis prevention, diagnosis, and therapy. JAMA. 2001;285(6):785-95.

3. Kanis JA, Melton LJ, Christiansen C, Johnston CC, Khaltaev N. The diagnosis of osteoporosis. J Bone Miner Res. 1994;9(8):1137-41.

4. General S. Bone health and osteoporosis: a report of the surgeon general. Rockville: US Department of Health and Human Services, Office of the Surgeon General; 2004.

5. Foundation NO. America's Bone Health: The State of Osteoporosis and Low Bone Mass in Our Nation. Washington, DC: National Osteoporsis Foundation; 2002.

6. Wright NC, Looker AC, Saag KG, Curtis JR, Delzell ES, Randall S, et al. The recent prevalence of osteoporosis and low bone mass in the United States based on bone mineral density at the femoral neck or lumbar spine. J Bone Miner Res. 2014;29(11):2520-6.

7. Cooper C, Campion G, Melton IL. Hip fractures in the elderly: a world-wide projection. Osteoporos Int. 1992;2(6):285-9.

8. Sambrook P, Cooper C. Osteoporosis. Lancet. 2006;367(9527):2010-8.

9. Looker AC, Orwoll ES, Johnston CC, Lindsay RL, Wahner HW, Dunn WL, et al. Prevalence of low femoral bone density in older US adults from NHANES III. J Bone Miner Res. 1997;12(11):1761-8.
10. Schnell K, Weiss CO, Lee T, Krishnan JA, Leff B, Wolff JL, et al. The prevalence of clinically-relevant comorbid conditions in patients with physician-diagnosed COPD: a cross-sectional study using data from NHANES 1999-2008. BMC Pulm Med. 2012;12(1):1.

11. Graat-Verboom L, Wouters E, Smeenk F, Van den Borne B, Lunde R, Spruit $M$. Current status of research on osteoporosis in COPD: a systematic review. Eur Respir J. 2009;34(1):209-18.

12. Majumdar SR, Villa-Roel C, Lyons KV, Rowe BH. Prevalence and predictors of vertebral fracture in patients with chronic obstructive pulmonary disease. Respir Med. 2010;104(2):260-6.

13. Nuti R, Siviero P, Maggi S, Guglielmi G, Caffarelli C, Crepaldi G, et al. Vertebral fractures in patients with chronic obstructive pulmonary disease: the EOLO Study. Osteoporos Int. 2009;20(6):989-98.

14. Huang S-W, Wang W-T, Chou L-C, Chen H-C, Liou T-H, Lin H-W. Chronic obstructive pulmonary disease increases the risk of hip fracture: $a$ nationwide population-based cohort study. Sci Rep. 2016;6:23360.

15. Siddiqui JA, Partridge NC. Physiological bone remodeling: systemic regulation and growth factor involvement. Physiology. 2016;31(3):233-45.

16. Manolagas SC. Birth and death of bone cells: basic regulatory mechanisms and implications for the pathogenesis and treatment of osteoporosis 1. Endocr Rev. 2000;21(2):115-37.

17. Clarke B. Normal bone anatomy and physiology. Clin J Am Soc Nephrol. 2008:3(Supplement 3):S131-9.

18. Lacey D, Timms E, Tan H-L, Kelley M, Dunstan C, Burgess T, et al. Osteoprotegerin ligand is a cytokine that regulates osteoclast differentiation and activation. Cell. 1998;93(2):165-76.

19. Patel MS, Karsenty G. Regulation of bone formation and vision by LRP5. N Engl J Med. 2002;346(20):1572-4.

20. Krishnan V, Bryant HU, MacDougald OA. Regulation of bone mass by Wnt signaling. J Clin Invest. 2006;116(5):1202-9.

21. Bai P, Sun Y, Jin J, Hou J, Li R, Zhang Q, et al. Disturbance of the OPG/ RANK/RANKL pathway and systemic inflammation in COPD patients with emphysema and osteoporosis. Respir Res. 2011;12(1):1.

22. Eagan TM, Ueland T, Wagner PD, Hardie JA, Mollnes TE, Damås JK, et al. Systemic inflammatory markers in COPD: results from the Bergen COPD Cohort Study. Eur Respir J. 2010;35(3):540-8.

23. Kneidinger N, Yildirim AO, Callegari J, Takenaka S, Stein MM, Dumitrascu R, et al. Activation of the WNT/B-catenin pathway attenuates experimental emphysema. Am J Respir Crit Care Med. 2011;183(6):723-33.

24. Bolton C, Stone M, Edwards P, Duckers J, Evans W, Shale D. Circulating matrix metalloproteinase- 9 and osteoporosis in patients with chronic obstructive pulmonary disease. Chron Respir Dis. 2009;6(2):81-7.

25. Garcia-Rio F, Miravitlles M, Soriano JB, Muñoz L, Duran-Tauleria E, Sánchez G, et al. Systemic inflammation in chronic obstructive pulmonary disease: a population-based study. Respir Res. 2010;1 1(1):1.

26. Sapey E, Ahmad A, Bayley D, Newbold P, Snell N, Rugman P, et al. Imbalances between interleukin-1 and tumor necrosis factor agonists and antagonists in stable COPD. J Clin Immunol. 2009;29(4):508-16.

27. Canalis E, Mazziotti G, Giustina A, Bilezikian J. Glucocorticoid-induced osteoporosis: pathophysiology and therapy. Osteoporos Int. 2007;18(10):1319-28.

28. Weinstein RS, Chen J-R, Powers CC, Stewart SA, Landes RD, Bellido T, et al. Promotion of osteoclast survival and antagonism of bisphosphonate-induced osteoclast apoptosis by glucocorticoids. J Clin Invest. 2002;109(8):1041-8.

29. Eijken M, Hewison M, Cooper M, De Jong F, Chiba H, Stewart P, et al. 11ß-Hydroxysteroid dehydrogenase expression and glucocorticoid synthesis are directed by a molecular switch during osteoblast differentiation. Mol Endocrinol. 2005;19(3):621-31.

30. Ohnaka K, Tanabe M, Kawate H, Nawata H, Takayanagi R. Glucocorticoid suppresses the canonical Wnt signal in cultured human osteoblasts. Biochem Biophys Res Commun. 2005;329(1):177-81.

31. Ohnaka K, Taniguchi H, Kawate H, Nawata H, Takayanagi R. Glucocorticoid enhances the expression of dickkopf-1 in human osteoblasts: novel mechanism of glucocorticoid-induced osteoporosis. Biochem Biophys Res Commun. 2004;318(1):259-64.

32. Jilka RL, Noble B, Weinstein RS. Osteocyte apoptosis. Bone. 2013;54(2):264-71.

33. Pufe T, Scholz-Ahrens KE, Franke AT, Petersen W, Mentlein R, Varoga D, et al. The role of vascular endothelial growth factor in glucocorticoid-induced bone loss: evaluation in a minipig model is. Bone. 2003;33(6):869-76.

34. Wang Y, Wan C, Deng L, Liu X, Cao X, Gilbert SR, et al. The hypoxiainducible factor a pathway couples angiogenesis to osteogenesis during skeletal development. J Clin Invest. 2007;117(6):1616-26. 
35. Jia D, O'brien C, Stewart S, Manolagas S, Weinstein R. Glucocorticoids act directly on osteoclasts to increase their life span and reduce bone density. Endocrinology. 2006;147(12):5592-9.

36. Calverley PM, Anderson JA, Celli B, Ferguson GT, Jenkins C, Jones PW, et al. Salmeterol and fluticasone propionate and survival in chronic obstructive pulmonary disease. N Engl J Med. 2007;356(8):775-89.

37. Calverley P, Pauwels R, Vestbo J, Jones P, Pride N, Gulsvik A, et al. Combined salmeterol and fluticasone in the treatment of chronic obstructive pulmonary disease: a randomised controlled trial. The Lancet. 2003;361(9356):449-56.

38. Jones $P$, Willits $L$, Burge $P$, Calverley P. Disease severity and the effect of fluticasone propionate on chronic obstructive pulmonary disease exacerbations. Eur Respir J. 2003;21(1):68-73.

39. Mahler DA, Wire P, Horstman D, Chang C-N, Yates J, Fischer T, et al. Effectiveness of fluticasone propionate and salmeterol combination delivered via the Diskus device in the treatment of chronic obstructive pulmonary disease. Am J Respir Crit Care Med. 2002;166(8):1084-91.

40. Davies L, Angus R, Calverley P. Oral corticosteroids in patients admitted to hospital with exacerbations of chronic obstructive pulmonary disease: a prospective randomised controlled trial. The Lancet. 1999;354(9177):456-60.

41. Maltais FO, Ostinelli J, Bourbeau J, Tonnel AB, Jacquemet N, Haddon J, et al. Comparison of nebulized budesonide and oral prednisolone with placebo in the treatment of acute exacerbations of chronic obstructive pulmonary disease: a randomized controlled trial. Am J Respir Crit Care Med. 2002;165(5):698-703.

42. Niewoehner DE, Erbland ML, Deupree RH, Collins D, Gross NJ, Light RW, et al. Effect of systemic glucocorticoids on exacerbations of chronic obstructive pulmonary disease. N Engl J Med. 1999;340(25):1941-7.

43. Thompson WH, Nielson CP, Carvalho P, Charan NB, Crowley JJ. Controlled trial of oral prednisone in outpatients with acute COPD exacerbation. Am J Respir Crit Care Med. 1996;154(2):407-12.

44. Alía I, Miguel A, Esteban A, Abella A, Ferrer R, Molina FJ, et al. Efficacy of corticosteroid therapy in patients with an acute exacerbation of chronic obstructive pulmonary disease receiving ventilatory support. Arch Intern Med. 2011;171(21):1939-46.

45. James S, Finch CK, Pinner NA. Corticosteroids in the treatment of acute exacerbations of chronic obstructive pulmonary disease. International Journal of COPD. 2014;9:421-30.

46. Lee TA, Weiss KB. Fracture risk associated with inhaled corticosteroid use in chronic obstructive pulmonary disease. Am J Respir Crit Care Med. 2004;169(7):855-9.

47. Kanis JA, Johansson $H$, Oden A, Johnell O, De Laet C, Melton LJ, et al. A meta-analysis of prior corticosteroid use and fracture risk. J Bone Miner Res. 2004;19(6):893-9.

48. Loke YK, Cavallazzi R, Singh S. Risk of fractures with inhaled corticosteroids in COPD: systematic review and meta-analysis of randomised controlled trials and observational studies. Thorax. 2011;66(8):699-708.

49. Van Staa T, Leufkens H, Cooper C. The epidemiology of corticosteroidinduced osteoporosis: a meta-analysis. Osteoporos Int. 2002;13(10):777-87.

50. Group LHSR. Effect of inhaled triamcinolone on the decline in pulmonary function in chronic obstructive pulmonary disease. N Engl J Med. 2000;2000(343):1902-9.

51. Pauwels RA, Löfdahl C-G, Laitinen LA, Schouten JP, Postma DS, Pride $\mathrm{NB}$, et al. Long-term treatment with inhaled budesonide in persons with mild chronic obstructive pulmonary disease who continue smoking. N Engl J Med. 1999;340(25):1948-53.

52. Johnell O, Pauwels R, Löfdahl C-G, Laitinen L, Postma D, Pride N, et al. Bone mineral density in patients with chronic obstructive pulmonary disease treated with budesonide Turbuhaler ${ }^{\circledR}$. Eur Respir J. 2002;19(6):1058-63.

53. Ferguson GT, Calverley PM, Anderson JA, Jenkins CR, Jones PW, Willits LR, et al. Prevalence and progression of osteoporosis in patients with COPD: results from the TOwards a Revolution in COPD Health study. CHEST Journal. 2009;136(6):1456-65.

54. Mathioudakis AG, Amanetopoulou SG, Gialmanidis IP, ChatzimavridouGrigoriadou V, Siasos G, Evangelopoulou E, et al. Impact of long-term treatment with low-dose inhaled corticosteroids on the bone mineral density of chronic obstructive pulmonary disease patients: aggravating or beneficial? Respirology. 2013;18(1):147-53.

55. Eastell R, Yergey AL, Vieira NE, Cedel SL, Kumar R, Riggs BL. Interrelationship among vitamin D metabolism, true calcium absorption, parathyroid function, and age in women: Evidence of an age-related intestinal resistance to 1, 25-dihydroxyvitamin D action. J Bone Miner Res. 1991;6(2):125-32.
56. Lips P. Vitamin D, deficiency and secondary hyperparathyroidism in the elderly: consequences for bone loss and fractures and therapeutic implications. Endocr Rev. 2001;22(4):477-501.

57. Holick MF, Binkley NC, Bischoff-Ferrari HA, Gordon CM, Hanley DA, Heaney $\mathrm{RP}$, et al. Evaluation, treatment, and prevention of vitamin D deficiency: an Endocrine Society clinical practice guideline. J Clin Endocrinol Metabol. 2011;96(7):1911-30.

58. Janssens W, Mathieu C, Boonen S, Decramer M. Vitamin D deficiency and chronic obstructive pulmonary disease: a vicious circle. Vitam Horm. 2010;86:379-99.

59. Førli L, Halse J, Haug E, Bjørtuft $\varnothing$, Vatn M, Kofstad J, et al. Vitamin D deficiency, bone mineral density and weight in patients with advanced pulmonary disease. J Intern Med. 2004;256(1):56-62.

60. Romme EA, Rutten EP, Smeenk FW, Spruit MA, Menheere PP, Wouters EF. Vitamin D status is associated with bone mineral density and functional exercise capacity in patients with chronic obstructive pulmonary disease. Ann Med. 2013;45(1):91-6.

61. Janssens W, Bouillon R, Claes B, Carremans C, Lehouck A, Buysschaert I, et al. Vitamin D deficiency is highly prevalent in COPD and correlates with variants in the vitamin D-binding gene. Thorax. 2010;65(3):215-20.

62. Muir SW, Montero-Odasso M. Effect of vitamin D supplementation on muscle strength, gait and balance in older adults: a systematic review and meta-analysis. J Am Geriatr Soc. 2011;59(12):2291-300.

63. Shuler M, Franklin D, Schlierf T, Wingate M. Preventing falls with vitamin D. 2014.

64. Riggs BL, Khosla S, Melton III LJ. Sex steroids and the construction and conservation of the adult skeleton. Endocr Rev. 2002;23(3):279-302.

65. Compston JE. Sex steroids and bone. Physiol Rev. 2001;81(1):419-47.

66. Callewaert F, Boonen S, Vanderschueren D. Sex steroids and the male skeleton: a tale of two hormones. Trends Endocrinol Metab. 2010;21(2):89-95.

67. Goderie-Plomp HW, van der Klift M, de Ronde W, Hofman A, de Jong FH, Pols HA. Endogenous sex hormones, sex hormone-binding globulin, and the risk of incident vertebral fractures in elderly men and women: the Rotterdam Study. J Clin Endocrinol Metabol. 2004;89(7):3261-9.

68. Balasubramanian V, Naing S. Hypogonadism in chronic obstructive pulmonary disease: incidence and effects. Curr Opin Pulm Med. 2012;18(2):112-7.

69. Bergmann P, Body JJ, Boonen S, Boutsen Y, Devogelaer JP, Goemaere S, Kaufman J, Reginster JY, Rozenberg S. Loading and skeletal development and maintenance. J Osteoporos. 2010;2011:786752. doi:10.4061/2011/786752.

70. Vico L, Collet P, Guignandon A, Lafage-Proust M-H, Thomas T, Rehailia M, et al. Effects of long-term microgravity exposure on cancellous and cortical weight-bearing bones of cosmonauts. The Lancet. 2000;355(9215):1607-11.

71. Leblanc AD, Schneider VS, Evans HJ, Engelbretson DA, Krebs JM. Bone mineral loss and recovery after 17 weeks of bed rest. J Bone Miner Res. 1990;5(8):843-50.

72. Heaney RP, Valent DJ, Barton IP. Hospitalization-related bone loss and the protective effect of risedronate. Osteoporos Int. 2006;17(2):212-6.

73. Johansson J, Nordström A, Nordström P. Objectively measured physical activity is associated with parameters of bone in 70-year-old men and women. Bone. 2015;81:72-9.

74. Schols AM, Soeters PB, Dingemans AM, Mostert R, Frantzen PJ, Wouters EF. Prevalence and characteristics of nutritional depletion in patients with stable COPD eligible for pulmonary rehabilitation. Am Rev Respir Dis. 1993;147(5):1151-6.

75. Vestbo J, Prescott E, Almdal T, Dahl M, Nordestgaard BG, Andersen T, et al. Body mass, fat-free body mass, and prognosis in patients with chronic obstructive pulmonary disease from a random population sample: findings from the Copenhagen City Heart Study. Am J Respir Crit Care Med. 2006;173(1):79-83.

76. Graat-Verboom L, Spruit MA, van den Borne BE, Smeenk FW, Martens EJ, Lunde $\mathrm{R}$, et al. Correlates of osteoporosis in chronic obstructive pulmonary disease: an underestimated systemic component. Respir Med. 2009;103(8):1143-51.

77. Bolton CE, lonescu AA, Shiels KM, Pettit RJ, Edwards PH, Stone MD, et al. Associated loss of fat-free mass and bone mineral density in chronic obstructive pulmonary disease. Am J Respir Crit Care Med. 2004;170(12):1286-93.

78. Ferrucci L, Baroni M, Ranchelli A, Lauretani F, Maggio M, Mecocci P, et al. Interaction between bone and muscle in older persons with mobility limitations. Curr Pharm Des. 2014;20(19):3178-97. 
79. Arnett TR. Acidosis, hypoxia and bone. Arch Biochem Biophys. 2010;503(1):103-9.

80. Park J, Park B, Kim H, Park T, Baek H. Hypoxia decreases Runx2/Cbfa1 expression in human osteoblast-like cells. Mol Cell Endocrinol. 2002;192(1):197-203.

81. Yohannes AM, Ershler WB. Anemia in COPD: a systematic review of the prevalence, quality of life, and mortality. Respir Care. 2011;56(5):644-52.

82. Chambellan A, Chailleux E, Similowski T. Prognostic value of the hematocrit in patients with severe COPD receiving long-term oxygen therapy. CHEST Journal. 2005;128(3):1201-8.

83. Cesari M, Pahor M, Lauretani F, Penninx BW, Bartali B, Russo R, et al. Bone density and hemoglobin levels in older persons: results from the InCHIANTI study. Osteoporos Int. 2005;16(6):691-9.

84. Bégin P, Grassino A. Inspiratory muscle dysfunction and chronic hypercapnia in chronic obstructive pulmonary disease. Am Rev Respir Dis. 1991;143(5 Pt 1):905-12.

85. Laitala $\mathrm{T}$, Väänänen $\mathrm{H}$. Inhibition of bone resorption in vitro by antisense RNA and DNA molecules targeted against carbonic anhydrase II or two subunits of vacuolar H [+]-ATPase. J Clin Investig. 1994;93(6):2311.

86. Ward KD, Klesges RC. A meta-analysis of the effects of cigarette smoking on bone mineral density. Calcif Tissue Int. 2001;68(5):259-70.

87. Ruan X, Mueck A. Impact of smoking on estrogenic efficacy. Climacteric. 2015;18(1):38-46.

88. Brot $\mathrm{C}$, Jorgensen $\mathrm{N}$, Sorensen $\mathrm{O}$. The influence of smoking on vitamin $\mathrm{D}$ status and calcium metabolism. Eur J Clin Nutr. 1999;53(12):920-6.

89. Duthie GG, Arthur JR, James W. Effects of smoking and vitamin E on blood antioxidant status. Am J Clin Nutr. 1991;53(4):1061S-3.

90. Yoon V, Maalouf N, Sakhaee K. The effects of smoking on bone metabolism. Osteoporos Int. 2012;23(8):2081-92.

91. Kiyokawa H, Muro S, Oguma T, Sato S, Tanabe N, Takahashi T, et al. Impact of COPD exacerbations on osteoporosis assessed by chest CT scan. COPD: J Chron Obstruct Pulmon Dis. 2012;9(3):235-42.

92. Stanojkovic I, Kotur-Stevuljevic J, Spasic S, Milenkovic B, Vujic T, Stefanovic A, et al. Relationship between bone resorption, oxidative stress and inflammation in severe COPD exacerbation. Clin Biochem. 2013;46(16):1678-82.

93. Abrams SA. Normal acquisition and loss of bone mass. Horm Res Paediatr. 2004;60 Suppl 3:71-6.

94. Pietria M, Lucarini S. The orthopaedic treatment of fragility fractures. Clin Cases Miner Bone Metab. 2007;4(2):108-16.

95. Gosch M, Kammerlander C, Roth T, Doshi H, Gasser R, Blauth M. Surgeons save bones: an algorithm for orthopedic surgeons managing secondary fracture prevention. Arch Orthop Trauma Surg. 2013;133(8):1101-8.

96. Kjensli A, Falch J, Ryg M, Blenk T, Armbrecht G, Diep L, et al. High prevalence of vertebral deformities in COPD patients: relationship to disease severity. Eur Respir J. 2009;33(5):1018-24.

97. Jørgensen N, Schwarz P, Holme I, Henriksen B, Petersen LJ, Backer V. The prevalence of osteoporosis in patients with chronic obstructive pulmonary disease-a cross sectional study. Respir Med. 2007;101(1):177-85.

98. Papaioannou A, Parkinson W, Ferko N, Probyn L, loannidis G, Jurriaans E, et al. Prevalence of vertebral fractures among patients with chronic obstructive pulmonary disease in Canada. Osteoporos Int. 2003;14(11):913-7.

99. McEVOY CE, Ensrud KE, Bender E, Genant HK, Yu W, Griffith JM, et al. Association between corticosteroid use and vertebral fractures in older men with chronic obstructive pulmonary disease. Am J Respir Crit Care Med. 1998;157(3):704-9.

100. Carter JD, Patel S, Sultan FL, Thompson ZJ, Margaux H, Sterrett A, et al. The recognition and treatment of vertebral fractures in males with chronic obstructive pulmonary disease. Respir Med. 2008;102(8):1165-72.

101. Barrett-Connor E, Nielson CM, Orwoll E, Bauer DC, Cauley JA. Epidemiology of rib fractures in older men: Osteoporotic Fractures in Men [MrOS] prospective cohort study. BMJ. 2010;340:c1069.

102. Harrison RA, Siminoski K, Vethanayagam D, Majumdar SR. Osteoporosisrelated kyphosis and impairments in pulmonary function: a systematic review. J Bone Miner Res. 2007;22(3):447-57.

103. Papaioannou A, Watts NB, Kendler DL, Yuen CK, Adachi JD, Ferko N. Diagnosis and management of vertebral fractures in elderly adults. Am J Med. 2002;113(3):220-8.

104. Silverman SL, Minshall ME, Shen W, Harper KD, Xie S. The relationship of health-related quality of life to prevalent and incident vertebral fractures in postmenopausal women with osteoporosis: results from the multiple outcomes of raloxifene evaluation study. Arthritis Rheum. 2001; 44(11):2611-9.
105. Cooper C, Atkinson EJ, MichaelO'Fallon W, Melton JL. Incidence of clinically diagnosed vertebral fractures: a population-based study in Rochester, Minnesota, 1985-1989. J Bone Miner Res. 1992;7(2):221-7.

106. Cooper C, Melton 3rd L. Vertebral fractures. BMJ [Br Med J]. 1992;304(6842):1634.

107. Lindsay R, Silverman SL, Cooper C, Hanley DA, Barton I, Broy SB, et al. Risk of new vertebral fracture in the year following a fracture. Jama. 2001;285(3):320-3.

108. Miyamoto RG, Kaplan KM, Levine BR, Egol KA, Zuckerman JD. Surgical management of hip fractures: an evidence-based review of the literature. I: femoral neck fractures. J Am Acad Orthop Surg. 2008;16(10):596-607.

109. Dell R, Greene D. Is osteoporosis disease management cost effective? Curr Osteoporos Rep. 2010;8(1):49-55.

110. Morris A, Zuckerman J, AAOS Council of Health Policy and Practice, USA. American Academy of Orthopaedic Surgeons. National consensus conference on improving the continuum of care for patients with hip fracture. J Bone Joint Surg Am. 2002;84(4):670-4.

111. Friedman SM, Mendelson DA. Epidemiology of fragility fractures. Clin Geriatr Med. 2014;30(2):175-81.

112. de Luise C, Brimacombe M, Pedersen L, Sørensen HT. Chronic obstructive pulmonary disease and mortality following hip fracture: a population-based cohort study. Eur J Epidemiol. 2008;23(2):115-22.

113. Hippisley-Cox J, Coupland C. Derivation and validation of updated QFracture algorithm to predict risk of osteoporotic fracture in primary care in the United Kingdom: prospective open cohort study. 2012.

114. Morden N, Sullivan S, Bartle B, Lee TA. Skeletal health in men with chronic lung disease: rates of testing, treatment, and fractures. Osteoporos Int. 2011;22(6):1855-62.

115. Nguyen TV, Center JR, Eisman JA. Osteoporosis: underrated, underdiagnosed and undertreated. Med J Aust. 2004;180(5):S18.

116. Delmas PD, van de Langerijt L, Watts NB, Eastell R, Genant H, Grauer A, et al. Underdiagnosis of vertebral fractures is a worldwide problem: the IMPACT study. J Bone Miner Res. 2005;20(4):557-63.

117. Harper C, FitzPatrick SK, Rozental TD, Herder L. Distal radius fractures in older men: a missed opportunity? J Hand Surg. 2013;38(10):e4.

118. Kanis JA, Oden A, Johansson H, Borgström F, Ström O, McCloskey E. FRAX ${ }^{\odot}$ and its applications to clinical practice. Bone. 2009;44(5):734-43.

119. Graat-Verboom L, van den Borne BE, Smeenk FW, Spruit MA, Wouters EF. Osteoporosis in COPD outpatients based on bone mineral density and vertebral fractures. J Bone Miner Res. 2011;26(3):561-8.

120. Ogura-Tomomatsu H, Asano K, Tomomatsu K, Miyata J, Ohmori N, Kodama M, et al. Predictors of osteoporosis and vertebral fractures in patients presenting with moderate-to-severe chronic obstructive lung disease. COPD: J Chron Obstruct Pulmon Dis. 2012:9(4):332-7.

121. Dennison EM, Compston JE, Flahive J, Siris ES, Gehlbach SH, Adachi JD, et al. Effect of co-morbidities on fracture risk: findings from the Global Longitudinal Study of Osteoporosis in Women [GLOW]. Bone. 2012;50(6):1288-93.

122. Romme EA, Geusens P, Lems WF, Rutten EP, Smeenk FW, van den Bergh JP, et al. Fracture prevention in COPD patients; a clinical 5-step approach. Respir Res. 2015;16(1):1.

123. Cosman F, De Beur S, LeBoff M, Lewiecki E, Tanner B, Randall S, et al. Clinician's guide to prevention and treatment of osteoporosis. Osteoporos Int. 2014;25(10):2359-81.

124. Cummings SR, Bates D, Black DM. Clinical use of bone densitometry: scientific review. Jama. 2002;288(15):1889-97.

125. Kanis JA. Assessment of fracture risk and its application to screening for postmenopausal osteoporosis: synopsis of a WHO report. Osteoporos Int. 1994;4(6):368-81.

126. Shepherd JA, Schousboe JT, Broy SB, Engelke K, Leslie WD. Executive summary of the 2015 ISCD position development conference on advanced measures from DXA and QCT: fracture prediction beyond BMD. J Clin Densitom. 2015;18(3):274-86.

127. Marshall D, Johnell O, Wedel H. Meta-analysis of how well measures of bone mineral density predict occurrence of osteoporotic fractures. BMJ. 1996;312(7041):1254-9.

128. Link TM. Osteoporosis imaging: state of the art and advanced imaging. Radiology. 2012;263(1):3-17.

129. Bonnick SL. Dual-energy x-ray absorptiometry: interpreting reports and serial measurements. Clin Obstet Gynecol. 2013;56(4):677-85.

130. Langhammer A, Forsmo S, Syversen U. Long-term therapy in COPD: any evidence of adverse effect on bone? 2009. 
131. Clark E, Carter L, Gould V, Morrison L, Tobias J. Vertebral fracture assessment [VFA] by lateral DXA scanning may be cost-effective when used as part of fracture liaison services or primary care screening. Osteoporos Int. 2014;25(3):953-64.

132. Van der Jagt-Willems $H$, van Munster $B$, Leeflang M, Beuerle E, Tulner C, Lems W. Diagnosis of vertebral fractures on lateral chest X-ray: intraobserver agreement of semi-quantitative vertebral fracture assessment. Eur J Radiol. 2014;83(12):2177-80.

133. Vogt TM, Ross PD, Palermo L, Musliner T, Genant HK, Black D, et al. Vertebral fracture prevalence among women screened for the fracture intervention trial and a simple clinical tool to screen for undiagnosed vertebral fractures. Mayo Clinic Proceedings. Elsevier; 2000.

134. Burch J, Rice S, Yang H, Neilson A, Stirk L, Francis R, et al. Systematic review of the use of bone turnover markers for monitoring the response to osteoporosis treatment: the secondary prevention of fractures, and primary prevention of fractures in high-risk groups. 2014.

135. Leuppi JD, Schuetz P, Bingisser R, Bodmer M, Briel M, Drescher T, et al. Short-term vs conventional glucocorticoid therapy in acute exacerbations of chronic obstructive pulmonary disease: the REDUCE randomized clinical trial. Jama. 2013;309(21):2223-31.

136. Maurel D, Boisseau N, Benhamou C, Jaffre C. Alcohol and bone: review of dose effects and mechanisms. Osteoporos Int. 2012;23(1):1-16.

137. Fiore M. How to prevent the progression of chronic bronchitis: the role of smoking cessation prevention. Monaldi Arch Chest Dis. 1994;49(3 Suppl 1):13-6.

138. Oncken C, Prestwood K, Kleppinger A, Wang Y, Cooney J, Raisz L. Impact of smoking cessation on bone mineral density in postmenopausal women. J Womens Health. 2006;15(10):1141-50.

139. Reid WD, Yamabayashi C, Goodridge D, Chung F, Hunt MA, Marciniuk DD, et al. Exercise prescription for hospitalized people with chronic obstructive pulmonary disease and comorbidities: a synthesis of systematic reviews: University of British Columbia. 2015

140. Spruit MA, Singh SJ, Garvey C, ZuWallack R, Nici L, Rochester C, et al. An official American Thoracic Society/European Respiratory Society statement: key concepts and advances in pulmonary rehabilitation. Am J Respir Crit Care Med. 2013;188(8):e13-64.

141. Howe TE, Shea B, Dawson LJ, Downie F, Murray A, Ross C, et al. Exercise for preventing and treating osteoporosis in postmenopausal women. The Cochrane Library. 2011.

142. Sherrington C, Whitney JC, Lord SR, Herbert RD, Cumming RG, Close JC. Effective exercise for the prevention of falls: a systematic review and meta-analysis. J Am Geriatr Soc. 2008;56(12):2234-43.

143. Lehouck A, Boonen S, Decramer M, Janssens W. COPD, bone metabolism, and osteoporosis. CHEST Journal. 2011;139(3):648-57.

144. Larsen ER, Mosekilde L, Foldspang A. Vitamin D and calcium supplementation prevents osteoporotic fractures in elderly community dwelling residents: a pragmatic population-based 3-year intervention study. J Bone Miner Res. 2004;19(3):370-8.

145. Ross AC, Taylor CL, Yaktine AL, Del Valle HB. Dietary reference intakes for calcium and vitamin D. Washington, DC: National Academies Press; 2011.

146. Vieth R. Vitamin D, toxicity, policy, and science. J Bone Miner Res. 2007;22(S2):V64-8.

147. Prentice RL, Pettinger M, Jackson R, Wactawski-Wende J, Lacroix A, Anderson $\mathrm{G}$, et al. Health risks and benefits from calcium and vitamin D supplementation: Women's Health Initiative clinical trial and cohort study. Osteoporos Int. 2013;24(2):567-80.

148. Reid IR, Bolland MJ. Calcium supplements: bad for the heart? Heart. 2012;98(12):895-6.

149. Bolland MJ, Avenell A, Baron JA, Grey A, MacLennan GS, Gamble GD, et al. Effect of calcium supplements on risk of myocardial infarction and cardiovascular events: meta-analysis. BMJ. 2010;341:c3691.

150. Brixen KT, Christensen B, Ejersted C, Langdahl BL. Teriparatide [biosynthetic human parathyroid hormone 1-34]: a new paradigm in the treatment of osteoporosis. Basic Clin Pharmacol Toxicol. 2004;94(6):260-70.

151. Neer RM, Arnaud CD, Zanchetta JR, Prince R, Gaich GA, Reginster J-Y, et al. Effect of parathyroid hormone [1-34] on fractures and bone mineral density in postmenopausal women with osteoporosis. N Engl J Med. 2001;344(19):1434-41.

152. Saag KG, Zanchetta JR, Devogelaer JP, Adler RA, Eastell R, See K, et al. Effects of teriparatide versus alendronate for treating glucocorticoid-induced osteoporosis: Thirty-six-month results of a randomized, double-blind, controlled trial. Arthritis Rheum. 2009;60(11):3346-55.
153. Saag KG, Shane E, Boonen S, Marín F, Donley DW, Taylor KA, et al. Teriparatide or alendronate in glucocorticoid-induced osteoporosis. N Engl J Med. 2007;357(20):2028-39.

154. Compston JE. The therapeutic use of bisphosphonates. BMJ [Br Med J]. 1994;309(6956):711.

155. Russell RGG. Bisphosphonates: mode of action and pharmacology. Pediatrics. 2007;119(Supplement 2):S150-62.

156. Bilezikian JP. Efficacy of bisphosphonates in reducing fracture risk in postmenopausal osteoporosis. Am J Med. 2009;122(2):S14-21.

157. Saag KG, Emkey R, Schnitzer TJ, Brown JP, Hawkins F, Goemaere S, et al. Alendronate for the prevention and treatment of glucocorticoid-induced osteoporosis. N Engl J Med. 1998;339(5):292-9.

158. Smith B, Laslett L, Pile K, Phillips P, Phillipov G, Evans SM, et al. Randomized controlled trial of alendronate in airways disease and low bone mineral density. Chron Respir Dis. 2004;1(3):131-7.

159. Watts NB, Diab DL. Long-term use of bisphosphonates in osteoporosis. J Clin Endocrinol Metabol. 2010;95(4):1555-65.

160. Stepan J, Alenfeld F, Boivin G, Feyen J, Lakatos P. Mechanisms of action of antiresorptive therapies of postmenopausal osteoporosis. Endocr Regul. 2003;37(4):225-38.

161. Chesnut $\mathrm{CH}$, Silverman S, Andriano K, Genant H, Gimona A, Harris S, et al. A randomized trial of nasal spray salmon calcitonin in postmenopausal women with established osteoporosis: the prevent recurrence of osteoporotic fractures study. Am J Med. 2000;109(4):267-76.

162. Overman RA, Borse M, Gourlay ML. Salmon calcitonin use and associated cancer risk. Ann Pharmacother. 2013;47(12):1675-84.

163. Silverman S, Azria M. The analgesic role of calcitonin following osteoporotic fracture. Osteoporos Int. 2002;13(11):858-67.

164. Lewiecki EM. Denosumab: a promising drug for the prevention and treatment of osteoporosis. 2006.

165. Cummings SR, Martin JS, McClung MR, Siris ES, Eastell R, Reid IR, et al. Denosumab for prevention of fractures in postmenopausal women with osteoporosis. N Engl J Med. 2009;361(8):756-65.

166. Miller PD, Bolognese MA, Lewiecki EM, McClung MR, Ding B, Austin M, et al. Effect of denosumab on bone density and turnover in postmenopausal women with low bone mass after long-term continued, discontinued, and restarting of therapy: a randomized blinded phase 2 clinical trial. Bone. 2008;43(2):222-9.

167. Miller P, Pannacciulli N, Brown J, Czerwinski E, Nedergaard B, Bolognese M, et al. Denosumab or Zoledronic Acid in Postmenopausal Women With Osteoporosis Previously Treated With Oral Bisphosphonates. J Clin Endocrinol Metab. 2016;101(8):3163-70.

168. Scott LJ. Denosumab: a review of its use in postmenopausal women with osteoporosis. Drugs Aging. 2014;31(7):555-76.

169. Tsai JN, Uihlein AV, Lee H, Kumbhani R, Siwila-Sackman E, McKay EA, et al. Teriparatide and denosumab, alone or combined, in women with postmenopausal osteoporosis: the DATA study randomised trial. Lancet. 2013;382(9886):50-6.

170. Gennari L, Merlotti D, Nuti R. Selective estrogen receptor modulator [SERM] for the treatment of osteoporosis in postmenopausal women: focus on lasofoxifene. 2010.

171. Ettinger B, Black DM, Mitlak BH, Knickerbocker RK, Nickelsen T, Genant HK, et al. Reduction of vertebral fracture risk in postmenopausal women with osteoporosis treated with raloxifene: results from a 3-year randomized clinical trial. Jama. 1999;282(7):637-45.

172. Sorensen O, Crawford G, Mulder H, Hosking D, Gennari C, Mellstrom D, et al. Long-term efficacy of risedronate: a 5-year placebo-controlled clinical experience. Bone. 2003;32(2):120-6.

173. Black DM, Bauer DC, Schwartz AV, Cummings SR, Rosen CJ. Continuing bisphosphonate treatment for osteoporosis_for whom and for how long? N Engl J Med. 2012;366(22):2051-3.

174. Srinath R, Dobs A. Enobosarm [GTx-024, S-22]: a potential treatment for cachexia. Future Oncol. 2014;10(2):187-94.

175. Ramos D, Bertolini GN, Leite MR, Junior LCSC, da Silva Pestana PR, dos Santos VR, et al. Is dynamometry able to infer the risk of muscle mass loss in patients with COPD? Int J Chron Obstruct Pulmon Dis. 2015;10:1403.

176. Baumgartner RN, Koehler KM, Gallagher D, Romero L, Heymsfield SB, Ross RR, et al. Epidemiology of sarcopenia among the elderly in New Mexico. Am J Epidemiol. 1998;147(8):755-63.

177. Janssen I, Shepard DS, Katzmarzyk PT, Roubenoff R. The healthcare costs of sarcopenia in the United States. J Am Geriatr Soc. 2004;52(1):80-5. 
178. Ferrari R, Caram LM, Faganello MM, Sanchez FF, Tanni SE, Godoy I. Relation between systemic inflammatory markers, peripheral muscle mass, and strength in limb muscles in stable COPD patients. Int J Chron Obstruct Pulmon Dis. 2015;10:1553.

179. Mostert R, Goris A, Weling-Scheepers C, Wouters E, Schols A. Tissue depletion and health related quality of life in patients with chronic obstructive pulmonary disease. Respir Med. 2000;94(9):859-67.

180. Engelen M, Schols A, Baken W, Wesseling G, Wouters E. Nutritional depletion in relation to respiratory and peripheral skeletal muscle function in out-patients with COPD. Eur Respir J. 1994;7(10):1793-7.

181. Landi F, Cruz-Jentoft AJ, Liperoti R, Russo A, Giovannini S, Tosato M, et al. Sarcopenia and mortality risk in frail older persons aged 80 years and older: results from ilSIRENTE study. Age Ageing. 2013;42(2):203-9.

182. Debigare $\mathrm{R}$, Cote $\mathrm{CH}$, Maltais F. Peripheral muscle wasting in chronic obstructive pulmonary disease: clinical relevance and mechanisms. Am J Respir Crit Care Med. 2001;164(9):1712-7.

183. Debigaré R, Marquis K, Côté $C H$, Tremblay RR, Michaud A, LeBlanc $P$, et al. Catabolic/anabolic balance and muscle wasting in patients with COPD. CHEST Journal. 2003;124(1):83-9.

184. Gosker H, Van Mameren H, Van Dijk P, Engelen M, Van der Vusse G, Wouters $E$, et al. Skeletal muscle fibre-type shifting and metabolic profile in patients with chronic obstructive pulmonary disease. Eur Respir J. 2002;19(4):617-25.

185. Gosker H, Hesselink M, Duimel H, Ward K, Schols A. Reduced mitochondrial density in the vastus lateralis muscle of patients with COPD. Eur Respir J. 2007;30(1):73-9.

186. Jakobsson P, Jorfeldt L, Henriksson J. Metabolic enzyme activity in the quadriceps femoris muscle in patients with severe chronic obstructive pulmonary disease. Am J Respir Crit Care Med. 1995;151(2):374-7.

187. Jobin J, Maltais F, Doyon J-F, LeBlanc P, Simard P-M, Simard A-A, et al. Chronic obstructive pulmonary disease: capillarity and fiber-type characteristics of skeletal muscle. J Cardiopulm Rehabil Prev. 1998;18(6):432-7.

188. Orozco-Levi M, Coronell C, Ramírez-Sarmiento A, Lloreta J, Martínez-Llorens J, Galdiz JB, Gea J. Injury of peripheral muscles in smokers with chronic obstructive pulmonary disease. Ultrastruct Pathol. 2012;36(4):228-38.

189. Gea J, Agustí A, Roca J. Pathophysiology of muscle dysfunction in COPD. J Appl Physiol. 2013;114(9):1222-34

190. Pitsiou G, Kyriazis G, Hatzizisi O, Argyropoulou P, Mavrofridis E, Patakas D. Tumor necrosis factor - alpha serum levels, weight loss and tissue oxygenation in chronic obstructive pulmonary disease. Respir Med. 2002; 96(8):594-8.

191. Brunelle J, Chandel N. Oxygen deprivation induced cell death: an update. Apoptosis. 2002;7(6):475-82.

192. Gonzalez NC, Wood JG. Alveolar hypoxia-induced systemic inflammation: what low PO2 does and does not do. Oxygen Transport to Tissue XXXI: Springer; 2010. p. 27-32.

193. Glass DJ. Skeletal muscle hypertrophy and atrophy signaling pathways. Int J Biochem Cell Biol. 2005;37(10):1974-84.

194. Reid MB, Lännergren J, Westerblad H. Respiratory and limb muscle weakness induced by tumor necrosis factor-a: involvement of muscle myofilaments. Am J Respir Crit Care Med. 2002;166(4):479-84.

195. Vilaró J, Ramirez-Sarmiento A, Martínez-Llorens JM, Mendoza T, Alvarez M, Sánchez-Cayado N, et al. Global muscle dysfunction as a risk factor of readmission to hospital due to COPD exacerbations. Respir Med. 2010; 104(12):1896-902.

196. Gea J, Casadevall C, Pascual S, Orozco-Levi M, Barreiro E. Respiratory diseases and muscle dysfunction. Expert Rev Respir Med. 2012;6(1):75-90.

197. Gea J, Barreiro E, Orozco-Levi M. Free radicals, cytokines, and respiratory muscles in COPD patients. Clin Pulm Med. 2007;14(3):117-26.

198. Rafferty GF, Lou Harris M, Polkey MI, Greenough A, Moxham J. Effect of hypercapnia on maximal voluntary ventilation and diaphragm fatigue in normal humans. Am J Respir Crit Care Med. 1999;160(5):1567-71.

199. England BK, Chastain JL, Mitch WE. Abnormalities in protein synthesis and degradation induced by extracellular $\mathrm{pH}$ in $\mathrm{BC} 3 \mathrm{H} 1$ myocytes. Am J Physiol Cell Physiol. 1991;260(2):C277-82.

200. Sanders KJ, Kneppers AE, van de Bool C, Langen RC, Schols AM. Cachexia in chronic obstructive pulmonary disease: new insights and therapeutic perspective. J Cachexia Sarcopenia Muscle. 2016;7(1):5-22.

201. Barreiro E, Peinado VI, Galdiz JB, Ferrer E, Marin-Corral J, Sánchez F, et al. Cigarette smoke-induced oxidative stress: a role in chronic obstructive pulmonary disease skeletal muscle dysfunction. Am J Respir Crit Care Med. 2010;182(4):477-88.
202. Ramsay D, Zochodne D, Robertson D, Nag S, Ludwin S. A syndrome of acute severe muscle necrosis in intensive care unit patients. J Neuropathol Exp Neurol. 1993;52(4):387-98.

203. Decramer M, De Bock V, Dom R. Functional and histologic picture of steroid-induced myopathy in chronic obstructive pulmonary disease. Am J Respir Crit Care Med. 1996;153(6):1958-64.

204. Calvani R, Miccheli A, Landi F, Bossola M, Cesari M, Leeuwenburgh C, et al. Current nutritional recommendations and novel dietary strategies to manage sarcopenia. J Frailty Aging. 2013;2(1):38.

205. Landi F, Marzetti E, Martone AM, Bernabei R, Onder G. Exercise as a remedy for sarcopenia. Curr Opin Clin Nutr Metab Care. 2014;17(1):25-31.

206. Kuh D, Bassey EJ, Butterworth S, Hardy R, Wadsworth ME, Team MS. Grip strength, postural control, and functional leg power in a representative cohort of British men and women: associations with physical activity, health status, and socioeconomic conditions. J Gerontol A Biol Sci Med Sci. 2005; 60(2):224-31.

207. Bossenbroek L, de Greef MH, Wempe JB, Krijnen WP, ten Hacken NH. Daily physical activity in patients with chronic obstructive pulmonary disease: a systematic review. COPD: J Chron Obstruct Pulmon Dis. 2011:8(4):306-19.

208. Gea J, Orozco-Levi M, Barreiro E, Ferrer A, Broquetas J. Structural and functional changes in the skeletal muscles of COPD patients: the"compartments" theory. Monaldi Arch Chest Dis. 2001;56(3):214-24.

209. Chopard A, Hillock S, Jasmin BJ. Molecular events and signalling pathways involved in skeletal muscle disuse-induced atrophy and the impact of countermeasures. J Cell Mol Med. 2009;13(9b):3032-50.

210. Maltais F, LeBlanc P, Simard C, Jobin J, Bérubé C, Bruneau J, et al. Skeletal muscle adaptation to endurance training in patients with chronic obstructive pulmonary disease. Am J Respir Crit Care Med. 1996;154(2):442-7.

211. O'Shea SD, Taylor NF, Paratz JD. Progressive resistance exercise improves muscle strength and may improve elements of performance of daily activities for people with COPD: a systematic review. CHEST Journal. 2009;136(5):1269-83.

212. Seymour J, Spruit M, Hopkinson N, Natanek S, Man W-C, Jackson A, et al. The prevalence of quadriceps weakness in COPD and the relationship with disease severity. Eur Respir J. 2010;36(1):81-8.

213. Cesari M, Leeuwenburgh C, Lauretani F, Onder G, Bandinelli S, Maraldi C, et al. Frailty syndrome and skeletal muscle: results from the Invecchiare in Chianti study. Am J Clin Nutr. 2006:83(5):1142-8.

214. Schols AM, Broekhuizen R, Weling-Scheepers CA, Wouters EF. Body composition and mortality in chronic obstructive pulmonary disease. Am J Clin Nutr. 2005;82(1):53-9.

215. Cruz-Jentoft AJ, Baeyens JP, Bauer JM, Boirie Y, Cederholm T, Landi F, et al. Sarcopenia: European consensus on definition and diagnosis Report of the European Working Group on Sarcopenia in Older People. Age Ageing. 2010;39(4):412-23.

216. Chen Z, Wang Z, Lohman T, Heymsfield SB, Outwater E, Nicholas JS, et al. Dual-energy $X$-ray absorptiometry is a valid tool for assessing skeletal muscle mass in older women. J Nutr. 2007;137(12):2775-80.

217. Chien MY, Huang TY, Wu YT. Prevalence of Sarcopenia Estimated Using a Bioelectrical Impedance Analysis Prediction Equation in CommunityDwelling Elderly People in Taiwan. J Am Geriatr Soc. 2008;56(9):1710-5.

218. Rolland Y, Czerwinski S, Van Kan GA, Morley J, Cesari M, Onder G, et al. Sarcopenia: its assessment, etiology, pathogenesis, consequences and future perspectives. J Nutr Health Aging. 2008;12(7):433-50.

219. Lauretani F, Russo CR, Bandinelli S, Bartali B, Cavazzini C, Di lorio A, et al. Age-associated changes in skeletal muscles and their effect on mobility: an operational diagnosis of sarcopenia. J Appl Physiol. 2003;95(5):1851-60.

220. Van Kan GA, Rolland Y, Andrieu S, Bauer J, Beauchet O, Bonnefoy M, et al. Gait speed at usual pace as a predictor of adverse outcomes in communitydwelling older people an International Academy on Nutrition and Aging [IANA] Task Force. J Nutr Health Aging. 2009;13(10):881-9.

221. Kamel HK. Sarcopenia and aging. Nutr Rev. 2003;61(5):157-67.

222. Roth S, Ferrell R, Hurley B. Strength training for the prevention and treatment of sarcopenia. J Nutr Health Aging. 1999:4(3):143-55.

223. Strasser B, Keinrad M, Haber P, Schobersberger W. Efficacy of systematic endurance and resistance training on muscle strength and endurance performance in elderly adults-a randomized controlled trial. Wien Klin Wochenschr. 2009;121(23-24):757-64.

224. Solberg PA, Kvamme NH, Raastad T, Ommundsen Y, Tomten SE, Halvari $H_{\text {, }}$ et al. Effects of different types of exercise on muscle mass, strength, function and well-being in elderly. Eur J Sport Sci. 2013;13(1):112-25. 
225. Ries AL, Bauldoff GS, Carlin BW, Casaburi R, Emery CF, Mahler DA, et al. Pulmonary rehabilitation: joint ACCP/AACVPR evidence-based clinical practice guidelines. CHEST Journal. 2007;131(5_suppl):4S-2.

226. Lan C-C, Chu W-H, Yang M-C, Lee C-H, Wu Y-K, Wu C-P. Benefits of pulmonary rehabilitation in patients with COPD and normal exercise capacity. Respir Care. 2013;58(9):1482-8.

227. Jones SE, Maddocks M, Kon SS, Canavan JL, Nolan CM, Clark AL, et al. Sarcopenia in COPD: prevalence, clinical correlates and response to pulmonary rehabilitation. Thorax. 2015;70(3):213-8.

228. Morley JE, Argiles JM, Evans WJ, Bhasin S, Cella D, Deutz NE, et al. Nutritional recommendations for the management of sarcopenia. J Am Med Dir Assoc. 2010;11(6):391-6.

229. Nass R, Pezzoli SS, Oliveri MC, Patrie JT, Harrell FE, Clasey JL, et al. Effects of an oral ghrelin mimetic on body composition and clinical outcomes in healthy older adults: a randomized trial. Ann Intern Med. 2008;149(9):601-11.

230. White HK, Petrie CD, Landschulz W, MacLean D, Taylor A, Lyles K, et al. Effects of an oral growth hormone secretagogue in older adults. J Clin Endocrinol Metabol. 2009;94(4):1198-206.

231. Angell MP, Chester N, Green D, Somauroo J, Whyte G, George K. Anabolic steroids and cardiovascular risk. Sports Med. 2012;42(2):119-34.

232. Basaria S, Coviello AD, Travison TG, Storer TW, Farwell WR, Jette AM, et al. Adverse events associated with testosterone administration. N Engl J Med. 2010;363(2):109-22.

233. Dalton JT, Barnette KG, Bohl CE, Hancock ML, Rodriquez D, Dodson ST, et al. The selective androgen receptor modulator GTX-024 [enobosarm] improves lean body mass and physical function in healthy elderly men and postmenopausal women: results of a double-blind, placebo-controlled phase II trial. J Cachex Sarcopenia Muscle. 2011;2(3):153-61.

234. Siriett V, Salerno MS, Berry C, Nicholas G, Bower R, Kambadur R, et al. Antagonism of myostatin enhances muscle regeneration during sarcopenia. Mol Ther. 2007;15(8):1463-70.

235. Busquets S, Toledo M, Orpí M, Massa D, Porta M, Capdevila E, et al. Myostatin blockage using actRIIB antagonism in mice bearing the Lewis lung carcinoma results in the improvement of muscle wasting and physical performance. J Cachex Sarcopenia Muscle. 2012;3(1):37-43.

\section{Submit your next manuscript to BioMed Central and we will help you at every step:}

- We accept pre-submission inquiries

- Our selector tool helps you to find the most relevant journal

- We provide round the clock customer support

- Convenient online submission

- Thorough peer review

- Inclusion in PubMed and all major indexing services

- Maximum visibility for your research

Submit your manuscript at www.biomedcentral.com/submit

) Biomed Central 